\title{
Zika virus during controlled ovarian hyperstimulation
}

\author{
Beuy Joob ${ }^{1}$, Viroj Wiwanitkit ${ }^{2}$ \\ ${ }^{1}$ Sanitation 1 Medical Academic Center, Bangkok Thailand \\ ${ }^{2}$ Honorary professor, dr DY Patil University, Pune, India
}

Dear Editor, we read the publication on "Case report of Zika virus during controlled ovarian hyperstimulation: results from follicular fluid, cumulus cells and oocytes" with a great interest. Filho et al. (2019) noted that "This is the first report in the literature analysing ZIKV in the follicular fluid, cumulus cells, and oocytes." Indeed, the identification of the virus in follicular fluid has been mentioned for a long time (Washington et al., 2016; Taitson et al., 2017). In animal model, the existence of the virus in oocytes is already reported (Broughton et al., 2017). Therefore, the report by Filho et al. (2019) should not be the first report.

\section{CONFLICT OF INTEREST}

None

\section{Corresponding author:}

Beuy Joob

Sanitation 1 Medical Academic Center

Bangkok Thailand

E-mail: beuyjoob@hotmail.com

\section{REFERENCES}

Broughton DE, Scheaffer S, Skaznik-Wikiel ME, Halabi J, Govero J, Caine M, Diamond M, Moley K. ZIKA virus exhibits tropism to the ovary and increases follicular apoptosis in a mouse model. Fertil Steril. 2017;108:e35.

Filho EA, Fácio CL, Machado-Paula LA, Oliveira MA, Martinhago $C D$, Araújo LP, Araújo LFP. Case report of Zika virus during controlled ovarian hyperstimulation: results from follicular fluid, cumulus cells and oocytes. JBRA Assist Reprod. 2019 Jan 7. [Epub ahead of print] PMID: 30614664 DOI: $10.5935 / 1518-0557.20180081$

Taitson PF, Souza VG, Santos ML. Zika virus outbreak: reproductive effects and decreases in the number of births in Brazil. JBRA Assist Reprod. 2017;21:293-4. PMID: 29192746 DOI: $10.5935 / 1518-0557.20170064$

Washington CI, Haque S, Segars JH, Bracero N, Rodriguez F, Ball GD, Davis OK. Keeping the Zika Virus Out of the Assisted Reproductive Technology Laboratory. Semin Reprod Med. 2016;34:293-8. PMID: 27618295 DOI: 10.1055/s0036-1592067 